\title{
MALIGNANT HYPERTHERMIA: A STATISTICAL REVIEW
}

\author{
B. A. BritT, M.D., DIP.ANaes.(ToR.), F.R.C.P.(c), AND W. Kalow, M.D. ${ }^{\circ}$
}

MaLignant HyPERTHERMIA, a condition characterized by fever and often skeletal muscle rigidity during general anaesthesia, has been reported many times in recent publications. ${ }^{1-64}$ The first recorded case occurred in $1922^{54}$ and the syndrome was first described in the literature in 1951 by Guedel. ${ }^{19}$ To date we are aware of over 170 such patients.

Because of the 64 per cent mortality associated with this rare disease (Table I), a review of the known cases appears to be worthwhile. Sufficient information was available to us, either from the literature ${ }^{1-42}$ or from personal communication, ${ }^{43-64}$ to permit summarization of the cases of 89 patients to whom 94 anaesthetics had

TABLE I

Number of Patients

\begin{tabular}{lccc}
\hline \hline & $\begin{array}{c}\text { Rigidity } \\
\text { present }\end{array}$ & $\begin{array}{c}\text { Rigidity absent } \\
\text { or not recorded }\end{array}$ & Total \\
\hline Survived & 24 & 8 & 32 \\
Died & 44 & 13 & 57 \\
Total & 68 & 21 & 89 \\
\hline$x$-square $=0.00$. & & & \\
$p=$ n.s. & & &
\end{tabular}

been administered. Even in these cases, in spite of considerable written correspondence, long distance telephone conversations, and personal visits to the physician or patient concerned, the available data were often incomplete, particularly in regard to the sequence of events.

The cases can be divided into two groups on the basis of presence or absence of skeletal muscle rigidity (Table I). As will be seen, the 71 anaesthetics (68 patients) characterized by rigidity differed in several important features from those cases not exhibiting rigidity.

\section{Preanaesthetic History: Incidence and Distribution}

Malignant hyperthermia during anaesthesia is undoubtedly rare, but apparently not as rare as the anaesthetic literature to date might lead one to think. During the past three or four years, the frequency of reported cases has been increasing, doubtless owing to the growing awareness of the problem by anaesthetists. However, many cases which do occur are probably never reported.

A rough estimate of the incidence in one section of the population may be

'Dr. Britt is in the Department of Anaesthesia and the Department of Pharmacology, University of Toronto; Dr. Kalow is in the Department of Pharmacology, University of Toronto.

Canad. Anaesth. Soc. J., vol. 17, no. 4, July 1970 
obtained from the following data. In the Hospital for Sick Children in Toronto, five cases have been observed. ${ }^{31-33}$ The first, which occurred about six years ago, resulted in the introduction of routine continuous thermometry during anaesthesia in that hospital. Thus, there is some assurance that no hyperthermic patients have since been overlooked. The total number of anaesthetics from that time was approximately 71,500 so that a crude estimate of the incidence would be about 1 in 14,000. The 95 per cent confidence limits of this estimate in round figures are between 1:6,800 and 1:38,000 (binomial limits). For the calculation of the lower limits of this estimate, the initial attention-drawing case has not been included. It must be recognized, of course, that incidence figures based on records of a children's hospital are not necessarily representative of a whole population since the frequency in children may not be the same as in adults.

The ages of all patients studied ranged from 3 to 56, with the highest incidence in the younger age groups. The age distribution is shown in Figure 1. It should be mentioned that recently a patient of 70 years of age, not included in this review, suffered a typical episode of malignant hyperthermia in the Albert Einstein College Hospital in New York. ${ }^{65}$

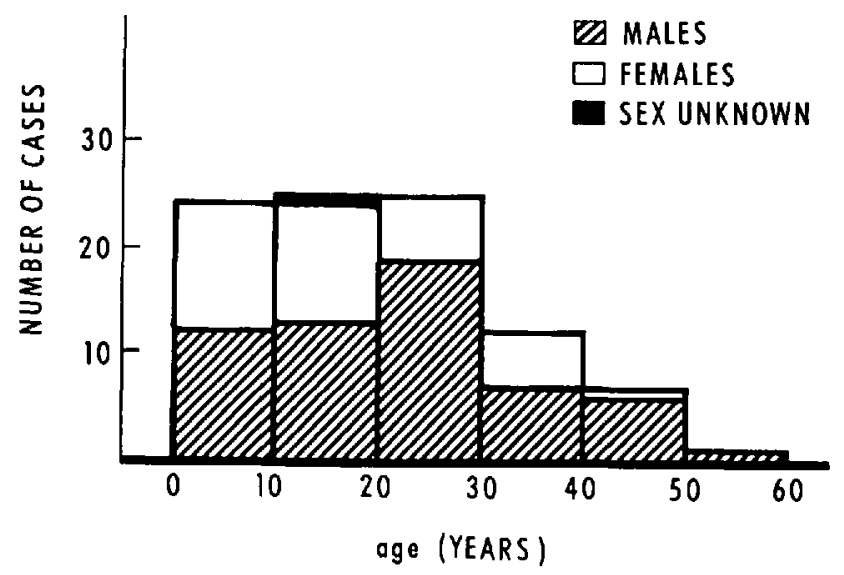

Figure 1. Age distribution of malignant hyperthermia.

The racial origin of the patients was varied. All three major racial groupsOriental, Negro and Caucasian - were involved (Table II). There were 55 males and 33 females. The sex of one patient was not stated. This distribution is statistically different from an expected ratio of $1: 1\left(\chi^{2}=5.2, p<0.03\right)$.

Multiple patients occurred in 14 independent families. ${ }^{2-4,6,12,14,15,29,31,33,48,50,52-54,}$ $56,57,60,62$ There were 60 affected individuals in these families, 31 of whom have been included in this review. The number of persons affected per family varied from two to twenty (Table III). As described more fully in a previous publication $^{3}$ the inheritance appeared to be autosomal dominant with reduced penetrance and variable expressivity. In spite of the preponderance of males, the inheritance cannot be sex-linked, since there is direct transmission from an affected father to an affected son and since the severity of the affliction does not appear to differ in the two sexes. 
TABLE II

Number of Patients

\begin{tabular}{lccc}
\hline \hline Racial origin & Males & Females & Unspecified \\
\hline Caucasian & 27 & 14 & 0 \\
Negro & 3 & 2 & 0 \\
Oriental & 4 & 0 & 0 \\
Unspecified & 21 & 17 & 1 \\
Total & 55 & 33 & 1 \\
\hline
\end{tabular}

TABLE III

\begin{tabular}{cc}
\hline $\begin{array}{c}\text { Number of } \\
\text { patients per } \\
\text { family }\end{array}$ & $\begin{array}{c}\text { Number of } \\
\text { families }\end{array}$ \\
\hline 1 & 58 \\
2 & 8 \\
3 & 3 \\
4 & 1 \\
11 & 1 \\
20 & 1 \\
Total & $118^{*}$ \\
\hline
\end{tabular}

*Besides the 89 patients on whom this review is based, this table includes 29 patients who are not counted or described elsewhere.

TABLE IV

Number of Patients

\begin{tabular}{|c|c|c|c|}
\hline $\begin{array}{c}\text { Muscle or } \\
\text { Musculo-skeletal } \\
\text { disease }\end{array}$ & $\begin{array}{l}\text { Rigidity } \\
\text { present }\end{array}$ & $\begin{array}{l}\text { Rigidity } \\
\text { absent or } \\
\text { not recorded }\end{array}$ & Total \\
\hline $\begin{array}{l}\text { Ptosis and strabismus } \\
\text { Idiopathic kypho-socliosis } \\
\text { Various hernias } \\
\text { Spontaneous muscle cramps } \\
\text { Miscellaneous }\end{array}$ & $\left.\begin{array}{l}8 \\
6 \\
5 \\
3 \\
7\end{array}\right\} 29$ & $\left.\begin{array}{l}1 \\
0 \\
2 \\
0 \\
0\end{array}\right\} 3$ & 32 \\
\hline No muscle disease observed & 39 & 18 & 57 \\
\hline Total & 68 & 21 & 89 \\
\hline
\end{tabular}

Thirty-two patients had pre-existing congenital muscle or musculoskeletal abnormalities ( Table IV). Most frequent of these were ptosis, strabismus, idiopathic kyphoscoliosis and various hernias - congenital inguinal hernia, umbilical hernia, and diaphragmatic hernia. A few patients also complained of a tendency to have severe muscle cramps in the extremities unrelated to either cold or exercise. Other abnormalities included recurrent spontaneous dislocations of joints, for example congenital dislocation of the hip joint, club foot and pes excavatum. All except three of the patients with pre-existing muscle or musculoskeletal disease developed skeletal muscle rigidity during general anaesthesia. Statistically this 
relationship was highly significant. Patients with a family history of malignant hyperthermia did not show a greater incidence of muscle or musculoskeletal disease than others (Table V). The distribution of type of operation for which the patients were anaesthetized reflected the incidence of musculoskeletal disease (Table VI). Twenty-two anaesthetics, i.e. 23.4 per cent of the total, were for orthopaedic procedures. In the Toronto General Hospital for the year 1965 the percentage was 8.2 (20,960 operations), and in the Hospital for Sick Children, Toronto, 13.4 (15,174 operations) during the same period $\left(\chi^{2}=8.90, p<0.008\right)$.

TABLE $V$

Number of Patients

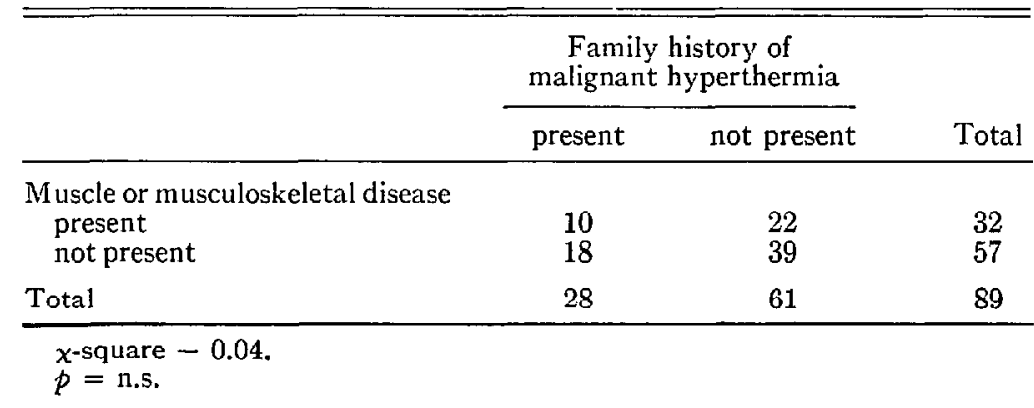

TABLE VI

Number of Anaesthetics

\begin{tabular}{lcc}
\hline $\begin{array}{l}\text { Type of } \\
\text { operation }\end{array}$ & $\begin{array}{c}\text { Rigidity } \\
\text { present }\end{array}$ & $\begin{array}{c}\text { Rigidity absent } \\
\text { or not recorded }\end{array}$ \\
\hline General & 17 & 9 \\
Orthopaedic & 19 & 3 \\
Plastic & 7 & 2 \\
Dental & 2 & 1 \\
Otolaryngological & 8 & 1 \\
Ophthalmological & 8 & 1 \\
Thoracic & 1 & 1 \\
Genito-urinary & 3 & 2 \\
Gynaecological & 3 & 2 \\
Type of operation & 3 & 1 \\
not specified & 71 & 23 \\
Total & & \\
\hline
\end{tabular}

The following observations regarding allergy were made. Urticaria developed in the arm into which succinylcholine was injected in one patient. ${ }^{38}$ In the preanaesthetic history, an eosinophil count elevated to 10 per cent was noted in one patient, ${ }^{38}$ red blotches following probanthine administration in a second,,$^{34}$ and urticaria or frank anaphylaxis subsequent to penicillin injection in four others. ${ }^{0,43,63,56}$

Three males and two females each developed malignant hyperthermia during each of two general anaesthetics (all of these anaesthetics were included in this review). ${ }^{31,38,42,62,54}$ Four other patients had also had general anaesthetics associated with hyperthermia, which were not included in this review for lack of sufficient data (Table VII). In three of the former cases the second anaesthetic 
technique was essentially similar to the first. ${ }^{38,42,52}$ In the third, succinylcholine and halothane were employed instead of ether and cyclopropane. ${ }^{54}$ In the fourth, succinylcholine was omitted and halothane substituted. ${ }^{31}$

One patient who had an episode of severe rigidity and mild hyperthermia failed to react in a similar manner during a subsequent anaesthetic. ${ }^{32}$ However, on the second occasion the anaesthetic technique was deliberately changed to intermittent intravenous meperidine, local laryngeal anaesthetic spray, and nitrous oxide and oxygen, while volatile anaesthetics and muscle relaxants were avoided.

TABLE VII

Number of Patients

\begin{tabular}{lccc}
\hline \hline & $\begin{array}{c}\text { Rigidity } \\
\text { present }\end{array}$ & $\begin{array}{c}\text { Rigidity absent } \\
\text { or not recorded }\end{array}$ & Total \\
\hline $\begin{array}{l}\text { Previous general anaesthesia } \\
\text { with hyperthermia }\end{array}$ & 6 & 3 & 9 \\
$\quad$ without hyperthermia & 17 & 4 & 21 \\
No previous general anaesthesia & 45 & 14 & 59 \\
Total & 68 & 21 & 89 \\
\hline
\end{tabular}

Twenty-one patients had had previous anaesthetics apparently without hyperthermia (Table VII). The reasons for the failure to develop malignant hyperthermia on first exposure to general anaesthetic agents has not yet been determined. However, this observation does indicate that many afflicted individuals in affected families have probably been overlooked and that the absence of hyperthermia during one anaesthetic does not rule out the possibility of its development during a future anaesthetic.

\section{Anaesthetic Management}

A considerable variety of preoperative anticholinergic and sedative drugs and induction agents were employed (Tables VIII, IX, X). The frequency of use of the different types of agents did not seem to be unusual. Rigidity occurred more frequently in the group of patients who received an anticholinergic agent than in the group which did not.

Succinylcholine was given to assist intubation in 73 anaesthetics. Prolonged rigidity, rather than the usual fasciculation-paralysis sequence, ensued in 59. Further doses of succinylcholine administered to 19 rigid patients intensified muscle stiffness in all. During twelve of the twenty-one anaesthetics in which succinylcholine was not employed, a somewhat delayed and slowly evolving rigidity developed (Table XI). While survival appeared to be slightly better in the group of patients who did not receive succinylcholine (Table XII), the difference was not statistically significant.

One patient who survived received curare as the sole relaxant agent. ${ }^{64}$ This patient did not display rigidity but did have an amazingly rapid rise in temperature from $97^{\circ}$ to $103.5^{\circ} \mathrm{F}$ within a few minutes in spite of the prophylactic use of a hypothermia blanket prior to the induction of the anaesthetic. Curare, gallamine 
TABLE VIII

Number of ANaesthetics

\begin{tabular}{lccc}
\hline \hline & $\begin{array}{c}\text { Rigidity } \\
\text { present }\end{array}$ & $\begin{array}{c}\text { Rigidity absent } \\
\text { or not recorded }\end{array}$ & Total \\
\hline $\begin{array}{l}\text { Anticholinergic agents } \\
\text { used }\end{array}$ & 62 & 12 & 74 \\
not used & 9 & 11 & 20 \\
Total & 71 & 23 & 94 \\
\hline$x$-square $=10.80$. & & & \\
$p<0.001$. & & &
\end{tabular}

TABLE IX

Number of ANaEsthetics

\begin{tabular}{lcc}
\hline \hline Preoperative sedatives & $\begin{array}{c}\text { Rigidity } \\
\text { present }\end{array}$ & $\begin{array}{c}\text { Rigidity absent } \\
\text { or not recorded }\end{array}$ \\
\hline Narcotics & 33 & 5 \\
Barbiturates & 4 & 0 \\
Tranquillizers & 3 & 0 \\
Narcotics and barbiturates & 10 & 7 \\
Barbiturates and tranquillizers & 1 & 0 \\
Narcotics and tranquillizers & 2 & 2 \\
Narcotics, barbiturates, and & 1 & 0 \\
tranquillizers & 17 & 9 \\
None known to have been given & 71 & 23 \\
Total & 71 \\
\hline
\end{tabular}

TABLE $\mathrm{X}$

NUMBER OF ANAESTHETICS

\begin{tabular}{lcc}
\hline \hline Induction agent & $\begin{array}{c}\text { Rigidity } \\
\text { present }\end{array}$ & $\begin{array}{c}\text { Rigidity absent } \\
\text { or not observed }\end{array}$ \\
\hline Thiopentone & 45 & 11 \\
Thiosecobarbitone & 1 & 1 \\
Methohexitone & 3 & 0 \\
Hexobarbitone & 1 & 0 \\
Tribromoethanol & 0 & 1 \\
Halothane & 7 & 0 \\
Ethylene & 2 & 0 \\
Cyclopropane & 3 & 4 \\
Thiopentone and cyclopropane & 1 & 0 \\
Thiosecobarbitone and halothane & 1 & 0 \\
Meperidine, chlorpromazine, & & 1 \\
promethazine, and nitrous oxide & 0 & 5 \\
Unknown & 7 & 23 \\
Total & 71 & \\
\hline
\end{tabular}

or n-allyl nortoxiferine was administered to twelve other patients following the initial infusion of succinylcholine. All except one of these patients were rigid (Table XIII), and in no case did these non-depolarizing agents produce any amelioration of the rigidity. On the contrary, their administration sometimes appeared to aggravate the stiffness in spite of the use of fairly large doses. Of further interest is the observation that all except one ${ }^{32}$ of the patients who received a non-depolarizing agent following an initial injection of succinylcholine suffered a 
TABLE XI

NUMBER OF ANAESTHETICS

\begin{tabular}{lccc}
\hline & $\begin{array}{c}\text { Rigidity } \\
\text { present }\end{array}$ & $\begin{array}{l}\text { Rigidity absent } \\
\text { or not recorded }\end{array}$ & Total \\
\hline Succinylcholine & & & \\
$\quad$ used & 59 & 14 & 73 \\
$\quad$ not used & 12 & 9 & 21 \\
Total & 71 & 23 & 94 \\
\hline$\chi$-square $=3.75$. & & & \\
$p<0.06$. & & &
\end{tabular}

TABLE XII

NuMBER OF ANAESTHETICS

\begin{tabular}{lccc}
\hline \hline & Died & Survived & Total \\
\hline Succinylcholine & & & \\
used & 47 & 26 & 73 \\
not used & 10 & 11 & 21 \\
Total & 57 & 37 & 94 \\
\hline
\end{tabular}

$x$-square $=1.28$.

$p=$ n.s.

TABLE XIII

Number OF ANAESTHETICS

\begin{tabular}{|c|c|c|c|}
\hline & Died & Survived & Total \\
\hline $\begin{array}{l}\text { Non-depolarizing } \\
\text { muscle relaxants } \\
\text { d-tubocurarine } \\
\text { gallamine } \\
\text { n-allyl nortoxiferine }\end{array}$ & $\left.\begin{array}{l}8 \\
2 \\
1\end{array}\right\} 11$ & $\left.\begin{array}{l}2^{*} \\
0 \\
0\end{array}\right\} 2$ & 13 \\
\hline none known to be used & 46 & 35 & 81 \\
\hline Total & 57 & 37 & 94 \\
\hline
\end{tabular}

cardiac arrest. This observation is supported by a case reported by Ryan ${ }^{66}$ too recently to be included in this review. Administration of curare to this patient was shortly followed by a cardiac arrest from which the patient was fortunately resuscitated.

Halothane, by far the most frequently employed potent inhalational anaesthetic agent (Table XIV), was given in 57 cases. Methoxyflurane, diethyl ether, cyclopropane, and ethylene were also employed in a few cases. The mortality associated with any of these agents did not appear to differ from the overall mortality rate, although the figures available for all anaesthetics except halothane were too small to enable a statistical analysis to be made. Three patients received no inhalational agent other than nitrous oxide, and all of these recovered.

Most of the commonly used anaesthetic gas circuits were employed. Although 
the total number of figures is rather small, it would appear that the circuits which were more apt to ensure a low inspired $\mathrm{CO}_{2}$ tension, such as the Ayres T-piece or the Magill A-circuit with a non-rebreathing valve, increased the chance for survival (Table XV).

TABLE XIV

Number of ANAESTHETICS

\begin{tabular}{|c|c|c|c|c|}
\hline \multirow{2}{*}{$\begin{array}{l}\text { Inhalational } \\
\text { anaesthetic } \\
\text { agent }\end{array}$} & \multicolumn{2}{|c|}{$\begin{array}{l}\text { Rigidity } \\
\text { present }\end{array}$} & \multicolumn{2}{|c|}{$\begin{array}{l}\text { Rigidity absent } \\
\text { or not recorded }\end{array}$} \\
\hline & died & survived & died & survived \\
\hline $\begin{array}{l}\text { Halothane } \\
\text { Methoxyflurane } \\
\text { Diethyl ether } \\
\text { Cyclopropane } \\
\text { Multiple potent agents } \\
\text { Nitrous oxide only } \\
\text { Not specified }\end{array}$ & $\begin{array}{r}31 \\
2 \\
1 \\
0 \\
10 \\
0 \\
0\end{array}$ & $\begin{array}{r}15 \\
0 \\
0 \\
0 \\
5 \\
2 \\
5\end{array}$ & $\begin{array}{l}9 \\
0 \\
1 \\
0 \\
2 \\
0 \\
1\end{array}$ & $\begin{array}{l}2 \\
0 \\
0 \\
2 \\
2 \\
1 \\
3\end{array}$ \\
\hline Total & 44 & 27 & 13 & 10 \\
\hline
\end{tabular}

TABLE XV

NUMBER OF ANAESTHETICS

\begin{tabular}{lccr}
\hline Gas machine circuit & Died & Survived & Total \\
\hline Closed circle & 6 & 2 & 8 \\
Semi-closed circle with & 24 & 7 & 31 \\
$\quad$ CO $_{2}$ absorber & 1 & 2 & 3 \\
Magill A with to and fro & 0 & 5 & 5 \\
$\quad$ rebreathing & 0 & 5 & 5 \\
Magill A with non-rebreathing & 26 & 16 & 42 \\
Ayres T-piece & 57 & 37 & 94 \\
Unknown & & & \\
Total & & &
\end{tabular}

$x$-square $=15.34$

$p<0.0001$.

\section{Clinical Signs of Malignant Hyperthermia}

Muscle tone

Skeletal muscle rigidity occurred in seventy-one anaesthetics (Table VI). The time of onset was variable. Often the first clinical feature to be noted was a sudden and profound rigidity of the jaw muscles following the initial administration of succinylcholine. Such rigidity often made endotracheal intubation difficult or even impossible ( 31 anaesthetics). In many patients who had received halothane without prior use of succinylcholine, the onset of the rigidity was delayed for up to an hour or even longer after the induction of the anaesthetic, and its development was rather insidious.

Fasciculations after succinylcholine were said to be more intense than usual in ten instances but completely absent in other cases. Violent shivering was noted in six patients during the application of hypothermia, but four other patients ap- 
parently did not shiver in spite of the use of cooling techniques. These contrasting statements are so puzzling that one is hesitant to attach much weight to them.

Five patients, all of whom were rigid and all of whom survived, complained of skeletal muscle pain or stiffness for several days postoperatively. In those patients who expired the muscle stiffness not infrequently merged imperceptibly into rigor mortis.

\section{Temperature}

Prior to anaesthesia the temperature was normal in all except three patients in whom slight elevations were attributed to mild infections. Between three minutes and four and a half hours after the induction of anaesthesia, the temperature was found to be elevated in all 94 anaesthetics, although exact records were not available for 14 cases (Table XVI). The maximum temperature attained varied from $100.1^{\circ} \mathrm{F}$ to $112^{\circ} \mathrm{F}$, with a median maximum temperature of $107.6^{\circ} \mathrm{F}$. There was a highly significant positive correlation between maximum temperature level and mortality. In the six cases in which the maximum temperature was less than $102.9^{\circ} \mathrm{F}$, anaesthesia was discontinued within three or four minutes of induction and all six patients recovered.

TABLE XVI

Number of ANAESTHETics

\begin{tabular}{lcccc}
\hline \hline $\begin{array}{c}\text { Maximum } \\
\text { temperature } \\
\left({ }^{\circ} \mathrm{F}\right)\end{array}$ & Died & Survived & Total & $\begin{array}{r}\text { Per cent } \\
\text { survival }\end{array}$ \\
\hline $99.0-102.9$ & 0 & 6 & 6 & 100 \\
$103.0-106.9$ & 9 & 14 & 23 & 61 \\
$107.0-110.9$ & 37 & 8 & 45 & 18 \\
$>111.0$ & 5 & 1 & 6 & 17 \\
Not specified & 6 & 8 & 14 & 57 \\
Total & 57 & 37 & 94 & 36 \\
\hline $\begin{array}{l}x \text {-square for significance of regression of survival on maximum tempera- } \\
\text { ture }=21.37 \text {. }\end{array}$ &
\end{tabular}

The rate of temperature rise was also variable, but in the majority of anaesthetics the rate varied from between $2.0^{\circ}$ and $8.0^{\circ} \mathrm{F}$ per hour (Table XVII), with a mean of $6.2^{\circ} \mathrm{F}$ per hour. The correlation between rate of temperature rise and mortality was not as marked as that between absolute maximum temperature and mortality, so that it would appear that absolute maximum temperature was a better prognostic indicator than was rate of temperature rise. However, the data for the rate of temperature rise must be interpreted with great caution, since for each patient one must assume that the temperature was measured accurately at least twice and that the time of each measurement was also accurately noted.

\section{Respiratory system (Table XVIII)}

Tachypnoea was observed in thirty anaesthetics. Occasionally tachypnoea was the first abnormality noted, usually in those patients who had no rigidity or in whom rigidity was delayed. Apnoea, unrelated to succinylcholine administration, 
developed in three cases as a consequence of skeletal muscle rigidity, and in a fourth case for unknown reasons.

Chest wall compliance was reduced in five patients, all of whom were rigid and all of whom died. No information regarding chest wall compliance was available for any of the remaining cases.

TABLE XVII

Number of ANaEsthetics

\begin{tabular}{ccccc}
\hline \hline $\begin{array}{c}\text { Rate of temperature } \\
\text { (rise in }{ }^{\circ} \text { F per hour) }\end{array}$ & Died & Survived & Total & $\begin{array}{c}\text { Per cent } \\
\text { survival }\end{array}$ \\
\hline $0-3.9$ & 8 & 5 & 13 & 38 \\
$4.0-7.9$ & 21 & 12 & 33 & 36 \\
$8.0-11.9$ & 5 & 2 & 7 & 29 \\
$>12.0$ & 3 & 0 & 3 & 0 \\
Not specified & 20 & 18 & 38 & 47 \\
Total & 57 & 37 & 94 & 36 \\
\hline
\end{tabular}

TABLE XVIII

NUMBER OF ANAESTHETICS

\begin{tabular}{lccc}
\hline & $\begin{array}{c}\text { Rigidity } \\
\text { present }\end{array}$ & $\begin{array}{l}\text { Rigidity absent } \\
\text { or not recorded }\end{array}$ & Total \\
\hline Respiratory rate & & & \\
$\quad$ increased & 27 & 3 & 30 \\
not increased & 44 & 20 & 64 \\
total & 71 & 23 & 94 \\
\hline$x$-square $=3.91$. & & & \\
$p<0.05$. & & &
\end{tabular}

\section{Cardiovascular system}

Tachycardia occurred during 68 anaesthetics (Table XIX). The rate varied from 108 to 200 per minute. In a number of these patients bradycardia super-

TABLE XIX

Number of ANAESThetics

\begin{tabular}{lccc}
\hline $\begin{array}{l}\text { Cardiovascular } \\
\text { abnormalities }\end{array}$ & $\begin{array}{c}\text { Rigidity } \\
\text { present }\end{array}$ & $\begin{array}{l}\text { Rigidity absent } \\
\text { or not recorded }\end{array}$ & Total \\
\hline $\begin{array}{l}\text { Heart rate* } \\
\text { increased }\end{array}$ & 55 & 13 & 68 \\
$\quad$ not increased & 16 & 10 & 26 \\
$\quad$ total & 71 & 23 & 94 \\
Arrhythmias & & & \\
yes & 32 & 21 & 34 \\
not observed & 39 & 23 & 60 \\
total & 71 & & 94 \\
Acute heart failure $\neq$ & & 0 & \\
yes & 9 & 23 & 85 \\
not observed & 62 & 23 & 94 \\
total & 71 & & \\
\hline$* \chi^{2}=2.83 ; p<0.10$. & & & \\
† $\chi^{2}=8.44 ; p<0.004$. & & & \\
$\ddagger \chi^{2}=1.93 ; p<0.17$. & &
\end{tabular}


vened a few minutes prior to cardiac arrest. Bradycardia, apparently not preceded by tachycardia, was observed in one patient; but in this person the initial measurement was made only a short time prior to cardiac arrest. One patient had a normal heart rate. In many of the reports the onset of tachycardia in relation to temperature rise was not clearly stated.

Arrhythmias other than sinus tachycardia were present in thirty-four cases. These included atrial and ventricular tachycardias, ventricular extrasystoles, and changes characteristic of hyperkalaemia (Table XIX).

Acute heart failure as evidenced by pulmonary or peripheral oedema, ascites, or sudden acute jugular venous distension was observed in nine patients all of whom were rigid (Table XIX).

\section{Kidneys (Table XX)}

Oliguria or frank anuria developed in seven patients, six of whom expired. A massive diuresis not preceded by oliguria occurred in one rather severely affected patient who had been early and vigorously treated with diuretics (mannitol and furosemide), buffers, and large volumes of intravenous fluids. This patient survived. ${ }^{57}$

TABLE XX

Number OF ANAESThetics

\begin{tabular}{lccr}
\hline & $\begin{array}{c}\text { Rigidity } \\
\text { present }\end{array}$ & $\begin{array}{c}\text { Rigidity absent } \\
\text { or not recorded }\end{array}$ & Total \\
\hline $\begin{array}{l}\text { Urine volume } \\
\text { decreased }\end{array}$ & 7 & 0 & 7 \\
not decreased or & 64 & 23 & 87 \\
not recorded & 71 & 23 & 94 \\
total & & & \\
$\quad \chi$-square $=1.23$. & & & \\
$p=$ n.s. & & &
\end{tabular}

Skin (Table XXI)

A variety of observations were made about the skin. The most common comment ( 33 cases), as might be expected, was that the skin was hot. Cyanosis was

TABLE XXI

Number of ANAESThetics

\begin{tabular}{lrcr}
\hline Skin & $\begin{array}{c}\text { Rigidity } \\
\text { present }\end{array}$ & $\begin{array}{c}\text { Rigidity absent } \\
\text { or not recorded }\end{array}$ & Total \\
\hline Moisture & & & \\
$\quad$ dry & 5 & 4 & 9 \\
$\quad$ sweating & 7 & 19 & 78 \\
$\quad$ not specified & 59 & 23 & 94 \\
$\quad$ total & 71 & & \\
Colour & & 1 & 36 \\
$\quad$ cyanosed & 35 & 22 & 58 \\
$\quad$ not cyanosed or skin & & 23 & 94 \\
$\quad$ colour not noted & 36 & & \\
$\quad$ total & 71 & &
\end{tabular}


noted in 36 patients and was often a very early finding. Other observations about the appearance of the skin tended to be quite contradictory. Comments about sweating, flushing, and vasodilatation each appeared to be about as frequent as comments about dryness, pallor, and vasoconstriction.

\section{Neurological system (Table XXII)}

Neurological findings, usually of late occurrence in the sequence of events, included unequal pupils, fixed and dilated pupils, localized muscle twitches, generalized convulsions, and coma. The outlook for survival was poor in patients who showed these changes. Only two patients with neurological abnormalities failed to develop rigidity of the skeletal muscles.

TABLE XXII

NUMBER OF ANAESThetics

\begin{tabular}{|c|c|c|c|c|c|}
\hline & \multicolumn{2}{|c|}{$\begin{array}{l}\text { Rigidity } \\
\text { present }\end{array}$} & \multicolumn{2}{|c|}{$\begin{array}{l}\text { Rigidity absent } \\
\text { or not recorded }\end{array}$} & \multirow[b]{2}{*}{ Total } \\
\hline & died & survived & died & survived & \\
\hline \multicolumn{6}{|c|}{ Late neurological deterioration } \\
\hline yes & 21 & 8 & 2 & 0 & 31 \\
\hline no & 23 & 19 & 11 & 10 & 63 \\
\hline total & 44 & 27 & 13 & 10 & 94 \\
\hline
\end{tabular}

$x$-square $=1.58 ; p=n . s$. for significance of neurological deterioration on rigidity.

$x$-square $=0.30 ; p=n .5$. for significance of neurological deterioration on mortality.

\section{Miscellaneous}

Infrequent miscellaneous findings included a brawny swelling of the parotid glands in one patient and bloody diarrhoea in another. Both of these patients were rigid and both died.

\section{Terminal events}

Cardiac arrest (usually in ventricular fibrillation) and death occurred in 57 of the 94 anaesthetics, so that the anaesthetic mortality rate was 60 per cent. Thus 57 of the 89 patients eventually died, making a patient mortality rate of 64 per cent. Resuscitation was attempted in all instances of cardiac arrest and was temporarily successful in ten cases, but no patients who arrested were permanently resuscitated (Table XXIII). ${ }^{*}$ Several patients had open as well as closed chest massage, and in these patients the heart muscle was reported to be in such an acute state of rigor that blood could neither enter nor leave the heart.

The longer the duration of anaesthesia the greater was the chance of a cardiac arrest and eventual death (Table XXIV). In fact all patients survived in whom anaesthesia was discontinued within ten minutes of induction.

The immediate cause of death in patients who expired early (during or immediately following anaesthesia) appeared to be an arrhythmia or a rigor of the heart muscle. In patients who died relatively late (usually after one or more days following anaesthesia) death was generally associated with massive electrolyte

* Since preparation of this paper, Ryan66 has reported several additional cases of malignant hyperthermia, in one of which the patient was successfully resuscitated from a cardiac arrest. 
TABLE XXIII

NUMBER OF ANAESTHETICS

\begin{tabular}{lcc}
\hline Cardiac arrest & $\begin{array}{c}\text { Rigidity } \\
\text { present }\end{array}$ & $\begin{array}{c}\text { Rigidity absent } \\
\text { or not recorded }\end{array}$ \\
\hline Yes with no & & 11 \\
resuscitation & 36 & 2 \\
Yes with temporary & 8 & 0 \\
resuscitation & 0 & 10 \\
resuscitation & 27 & 23 \\
No & 71 & \\
Total & & \\
\hline
\end{tabular}

TABLE XXIV

NUMBER OF ANAESTHETtCS

\begin{tabular}{lcccc}
\hline $\begin{array}{l}\text { Duration of } \\
\text { anaesthesia } \\
\text { (minutes) }\end{array}$ & Died & Survived & Total & $\begin{array}{r}\text { Per cent } \\
\text { survival }\end{array}$ \\
\hline $0-10$ & 0 & 5 & 5 & 100 \\
$11-40$ & 5 & 6 & 11 & 55 \\
$41-70$ & 9 & 3 & 12 & 25 \\
70 & 24 & 8 & 32 & 25 \\
Not specified & 19 & 15 & 34 & 44 \\
Total & 57 & 37 & 94 & 36 \\
\hline
\end{tabular}

$x$-square for significance of regression of survival on maximum tempera. ture $=8.38$.

$p<0.004$.

and acid-base disturbances, coagulation defects, renal failure, acute heart failure, and neurological deterioration.

All patients who survived recovered completely both mentally and physically, although the convalescent period was often stormy and extended over many days.

\section{Post Mortem Findings}

Thirty-four patients were autopsied. In the majority of cases nothing was found other than changes characteristic of acute terminal anoxia - for example fatty degeneration of the liver and widespread oedema, focal necrosis, petechial haemorrhages, and micro thrombi and emboli. Several pathologists also reported an acute rigor mortis of the skeletal muscles, ${ }^{27}$ slight hypertrophy of skeletal muscle fibres, ${ }^{40}$ haemoglobin casts in the renal tubules, ${ }^{56}$ and myoglobinuric nephrosis. ${ }^{38}$

\section{Laboratory Findings Characteristic of Malignant Hyperthermia}

\section{Blood gases (Table XXV)}

An arterial oxygen tension of less than $90 \mathrm{~mm} \mathrm{Hg}$ was observed in 37 rigid and three non-rigid cases, in spite of more than adequate artificial ventilation with an oxygen-enriched mixture and normal pulmonary function. Patients receiving oxygen-enriched mixtures almost invariably had wide alveolar-arterial oxygen 
tension gradients. There appeared to be no difference in arterial oxygen tension values between the rigid and non-rigid group of patients.

Arterial $\mathrm{CO}_{2}$ tension was elevated in 25 patients, all of whom were rigid. The maximum level varied from 47 to $179 \mathrm{~mm} \mathrm{Hg}$. In one patient an elevation to 100 $\mathrm{mm} \mathrm{Hg}$ was detected within a few minutes of the induction of the anaesthetic, prior to any temperature rise. ${ }^{32}$ While normal or low arterial $\mathrm{CO}_{2}$ tension values were recorded in five patients, all five were known to be receiving vigorous hyperventilation at the time of measurement.

Arterial blood $\mathrm{pH}$ was measured in 31 cases and found to be low in thirty (range 6.60 to 7.32 ) and normal in one (7.40). Rigidity was a feature in all 31 of these patients.

Metabolic acidosis as determined by calculation of base deficit was noted in 24 patients, 23 of whom were rigid. The deficit varied from -6 to $-30 \mathrm{mEq}$. A base excess was present in three rigid patients (range +3 to $+15 \mathrm{mEq}$ ). However, all three had been previously treated with sodium bicarbonate.

\section{Serum electrolytes (Table XXV)}

Serum potassium was elevated in sixteen rigid patients to between 5.2 and 19.0 $\mathrm{mEq} / \mathrm{L}$. In a few of these patients, the serum potassium subsequently fell to a very low level, for example to $1.9 \mathrm{mEq} / \mathrm{L}$ in the patient who had an initial reading of $19 \mathrm{mEq} / \mathrm{L} .{ }^{29}$ In seven other patients (six rigid and one non-rigid) all the serum potassium values recorded were normal or low $(3.0-4.9 \mathrm{mEq} / \mathrm{L})$. However, all of these latter measurements were made after treatment with diuretics, intravenous fluids, and buffers so that an early hyperkalaemia may have been missed.

TABLE XXV

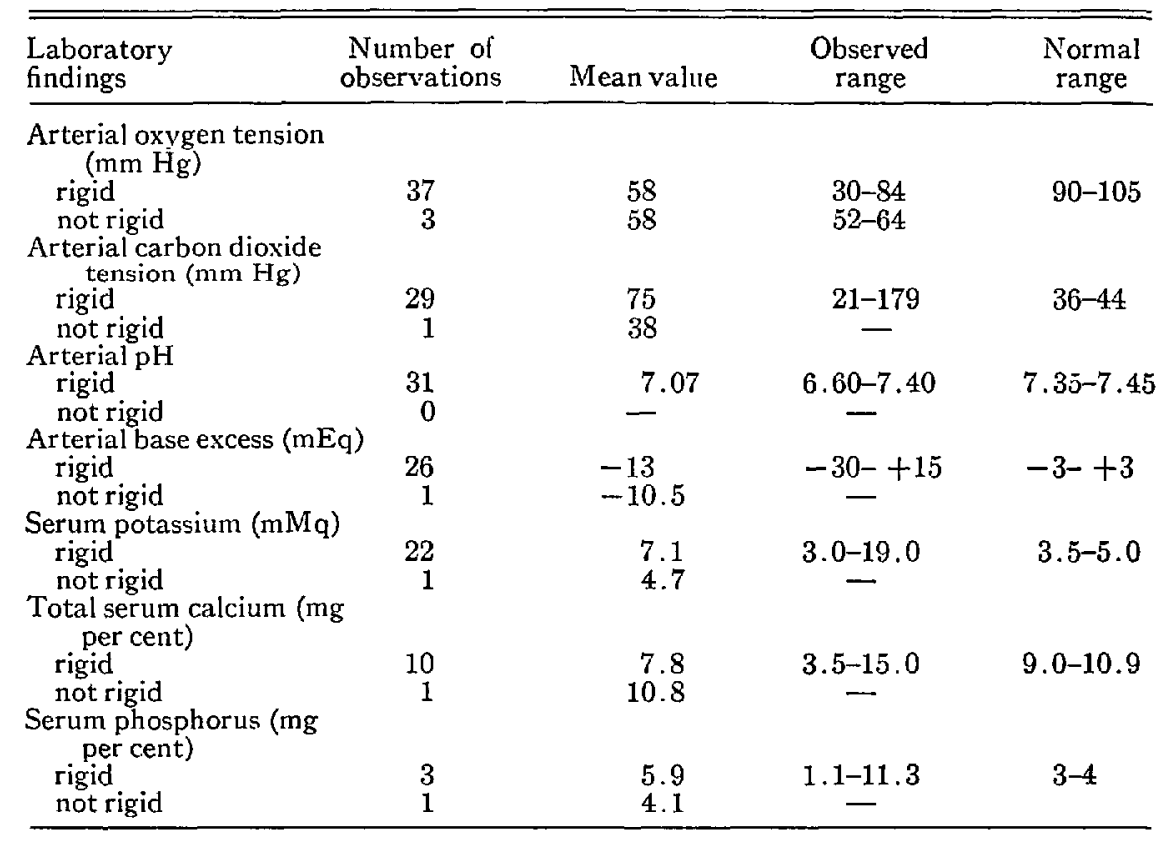


Measurements of serum calcium were made in eleven patients. All but one of the patients with low values exhibited rigidity. Serum phosphorus was low in one patient (1.1 $\mathrm{mg}$ per cent) and elevated in three (4.1-11.3 $\mathrm{mg}$ per cent).

\section{Serum enzymes (Table XXVI)}

Serum levels of such normally intracellular enzymes as the sGot (serum glutamic oxalic transaminase), SGPT (serum glutamic pyruvic transaminase), CPK (creatine phosphate kinase), LDH (lactic acid dehydrogenase) and LDH-HS (lactic acid dehydrogenase-heat stable) were elevated in ten patients following the development of rigidity. These elevated levels were detected on the first to third post operative days. Normal values for these enzymes were found in two patients, but both these measurements were made only on the day of the operation.

TABLE XXVI

Number of ANAEsthetics

\begin{tabular}{lcc}
\hline $\begin{array}{l}\text { Laboratory findings } \\
\text { Rigidity } \\
\text { present }\end{array}$ & $\begin{array}{c}\text { Rigidity absent } \\
\text { or not recorded }\end{array}$ \\
\hline $\begin{array}{l}\text { (CPK, SGOT, SGPT, } \\
\text { LDHH-HS) }\end{array}$ & & \\
normal & 10 & 0 \\
total & 1 & 1 \\
Blood coagulation & 11 & 1 \\
prolonged & & \\
normal & 14 & 1 \\
total & 4 & 0 \\
Urine myoglobin & 18 & 1 \\
$\quad$ and haemoglobin & & \\
present & & \\
absent & 17 & 4 \\
total & 3 & 4 \\
\hline
\end{tabular}

\section{Blood coagulation (Table XXVI)}

Blood coagulation was prolonged in fifteen patients, fourteen of whom became rigid and eleven of whom died. Blood coagulation was normal in four patients, all of whom survived. In the few patients in whom detailed coagulation studies were carried out ${ }^{11,29,58,63}$ the defect appeared to be due to excessive consumption of the blood clotting factors secondary to an accelerated rate of coagulation. Impaired blood clotting was usually first observed prior to the termination of anaesthesia but following the detection of rigidity, fever, tachypnoea, tachycardia, and cyanosis.

\section{Urinary heme pigments (Table XXVI)}

Rigidity was present in all seventeen patients in whom haemoglobinuria or myoglobinuria was detected. The tests were made only on the day of operation and not during the subsequent two or three days when one would have expected that leakage of these pigments out of the damaged cells and into the urine would be maximal. 


\section{Muscle biopsy}

While unfortunately no muscle specimens have ever been obtained from a patient during an acute episode of malignant hyperthermia, muscle biopsies were carried out on seven patients at some time subsequent to the acute episode. Both light and electron microscopy sections from three patients (two of whom did not become rigid) were within normal limits. ${ }^{31,64,67}$ Haematoxylin and eosin sections in three other patients - all rigid - showed normal staining, but sections fixed with osmic acid were characterized by round densities. Under the electron microscope, these appeared to be dense globules of lipid resulting from mitochondrial degeneration. $^{6}$ In a fourth rigid patient who was detected in Winnipeg by Dr. John Wade, electron microscopy ${ }^{62}$ showed a selective and patchy destruction of the sarcoplasmic reticulum.

\section{Management of Malignant Hyperthermia}

The frequency of use and effect on survival of the many pharmacological agents and other therapeutic measures which have been employed in the treatment of malignant hyperthermia are summarized in Table XXVII. Individually none appears to have improved the mortality rate. Several, in fact, may have worsened the

TABLE XXVII

NUMBER OF ANAESTHETICS

\begin{tabular}{|c|c|c|c|c|c|c|c|}
\hline \multirow[b]{2}{*}{ Problem } & \multirow[b]{2}{*}{$\begin{array}{c}\text { Treatment, agent } \\
\text { or technique }\end{array}$} & \multicolumn{2}{|c|}{ Died } & \multicolumn{2}{|c|}{ Survived } & \multirow[b]{2}{*}{$\chi^{2}$} & \multirow[b]{2}{*}{$p$} \\
\hline & & used & $\begin{array}{l}\text { not } \\
\text { used }\end{array}$ & used & $\begin{array}{l}\text { not } \\
\text { used }\end{array}$ & & \\
\hline Hyperthermia & $\begin{array}{l}\text { applied cooling, } \\
\text { phenothiazines, } \\
\text { aspirin supp. }\end{array}$ & $\begin{array}{r}34 \\
9 \\
3\end{array}$ & $\begin{array}{l}23 \\
48 \\
54\end{array}$ & $\begin{array}{r}26 \\
5 \\
1\end{array}$ & $\begin{array}{l}11 \\
32 \\
36\end{array}$ & $\begin{array}{l}0.68 \\
0.16 \\
0.01\end{array}$ & $\begin{array}{l}\text { n.s. } \\
, "\end{array}$ \\
\hline \multirow[t]{2}{*}{$\begin{array}{l}\text { Acidosis and } \\
\text { hypoxia }\end{array}$} & $\begin{array}{l}\text { buffers, } \\
\text { artificial hyper- }\end{array}$ & 26 & 31 & 14 & 23 & 0.28 & $"$ \\
\hline & $\begin{array}{l}\text { ventilation, } \\
100 \% \text { inspired oxygen }\end{array}$ & $\begin{array}{l}35 \\
28\end{array}$ & $\begin{array}{l}22 \\
29\end{array}$ & $\begin{array}{l}19 \\
16\end{array}$ & $\begin{array}{l}18 \\
21\end{array}$ & $\begin{array}{l}0.56 \\
0.12\end{array}$ & $"$ \\
\hline \multirow[t]{2}{*}{$\begin{array}{l}\text { Serum potassium } \\
\text { abnormality }\end{array}$} & $\begin{array}{l}\text { potassium salts, } \\
\text { insulin with glucose }\end{array}$ & $\begin{array}{r}20 \\
3\end{array}$ & 54 & $\begin{array}{r}10 \\
2\end{array}$ & 35 & 0.19 & $"$ \\
\hline & $\begin{array}{l}\text { infusion, } \\
\text { cation exchange resin }\end{array}$ & $\begin{array}{l}2 \\
1\end{array}$ & $\begin{array}{l}55 \\
56\end{array}$ & $\begin{array}{l}1 \\
0\end{array}$ & $\begin{array}{l}36 \\
37\end{array}$ & $\begin{array}{l}0.15 \\
0.05\end{array}$ & \\
\hline $\begin{array}{l}\text { Unstable and } \\
\text { leaky membranes }\end{array}$ & $\begin{array}{l}\text { calcium salts, } \\
\text { steroids }\end{array}$ & $\begin{array}{l}12 \\
19\end{array}$ & $\begin{array}{l}45 \\
38\end{array}$ & $\begin{array}{l}2 \\
8\end{array}$ & $\begin{array}{l}35 \\
29\end{array}$ & $\begin{array}{l}3.19 \\
0.99\end{array}$ & $" \prime$ \\
\hline $\begin{array}{l}\text { Coagulation } \\
\text { defects }\end{array}$ & $\begin{array}{l}\text { anticoagulants, } \\
\text { coagulants }\end{array}$ & $\begin{array}{r}2 \\
7\end{array}$ & $\begin{array}{l}55 \\
50\end{array}$ & $\begin{array}{l}1 \\
2\end{array}$ & $\begin{array}{l}36 \\
35\end{array}$ & $\begin{array}{l}0.15 \\
0.56\end{array}$ & $"$ \\
\hline $\begin{array}{l}\text { Renal } \\
\text { failure }\end{array}$ & $\begin{array}{l}\text { diuretics, } \\
\text { dialysis }\end{array}$ & $\begin{array}{l}7 \\
1\end{array}$ & $\begin{array}{l}50 \\
56\end{array}$ & $\begin{array}{l}3 \\
1\end{array}$ & $\begin{array}{l}34 \\
36\end{array}$ & $\begin{array}{l}0.07 \\
0.18\end{array}$ & " \\
\hline \multirow[t]{2}{*}{$\begin{array}{l}\text { Cardjovascular } \\
\text { abnormalities }\end{array}$} & $\begin{array}{l}\text { adrenergic } \alpha \\
\text { stimulators, } \\
\text { epinephrine, } \\
\text { adrenergic } \beta\end{array}$ & $\begin{array}{r}11 \\
4\end{array}$ & $\begin{array}{l}46 \\
53\end{array}$ & $\begin{array}{l}2 \\
1\end{array}$ & $\begin{array}{l}35 \\
36\end{array}$ & $\begin{array}{l}2.56 \\
0.19\end{array}$ & $"$ \\
\hline & $\begin{array}{l}\text { stimulators, } \\
\text { cholinergic agents, } \\
\text { anticholinergic agents, } \\
\text { cardiac glycosides, } \\
\text { antiarrhy thmic agents }\end{array}$ & $\begin{array}{l}4 \\
0 \\
3 \\
1 \\
5\end{array}$ & $\begin{array}{l}53 \\
57 \\
54 \\
56 \\
52\end{array}$ & $\begin{array}{l}1 \\
1 \\
2 \\
1 \\
1\end{array}$ & $\begin{array}{l}36 \\
36 \\
35 \\
36 \\
36\end{array}$ & $\begin{array}{l}0.19 \\
0.05 \\
0.19 \\
0.18 \\
0.55\end{array}$ & $\begin{array}{l}", \\
", \\
",\end{array}$ \\
\hline $\begin{array}{l}\text { Neurological } \\
\text { deterioration }\end{array}$ & $\begin{array}{l}\text { CNs stimulants } \\
\text { CNS depressants }\end{array}$ & $\begin{array}{l}4 \\
2\end{array}$ & $\begin{array}{l}53 \\
55\end{array}$ & $\begin{array}{l}0 \\
5\end{array}$ & $\begin{array}{l}37 \\
32\end{array}$ & $\begin{array}{l}1.26 \\
1.57\end{array}$ & " \\
\hline $\begin{array}{l}\text { Blood volume } \\
\text { deficiency }\end{array}$ & $\begin{array}{l}\text { IV electrolytes } \\
\text { and/or glucose } \\
\text { Plasma expanders } \\
\text { Blood }\end{array}$ & $\begin{array}{r}19 \\
6 \\
8\end{array}$ & $\begin{array}{l}38 \\
51 \\
49\end{array}$ & $\begin{array}{r}12 \\
2 \\
2\end{array}$ & $\begin{array}{l}25 \\
35 \\
35\end{array}$ & $\begin{array}{l}0.02 \\
0.24 \\
0.97\end{array}$ & "" \\
\hline
\end{tabular}


BRITT \& KALOW: MALIGNANT HYPERTHERMIA: A STATISTICAL REVIEW

chance for survival. Further information regarding the efficacy of various treatments can probably be obtained from examination of the management of certain individual cases rather than from a statistical analysis of the whole.

\section{Hyperthermia (Table XXVII)}

The application of cooling was frequently so long delayed and applied in such a desultory manner that the temperature not only failed to drop but in some cases continued to rise. Those patients who did survive usually had had every square inch of their skin surface in contact with the cooling fluid and in addition had been given some form of internal cooling-gastric, rectal, or wound. Once the fever had been brought under control, cooling was in several instances carried on for too long with a resulting hypothermia that proved to be just as deleterious as the preceding hyperthermia.

In a few recent patients, careful continuous temperature records would appear to indicate that phenothiazines such as chlorpromazine did accelerate the rate of temperature fall, if given early and in conjunction with active cooling measures. ${ }^{5,30,43,57}$

\section{Metabolic acidosis (Table XXVII)}

In many instances buffers appear to have been administered much too late in the course of the disease and in amounts which were inadequate to ccrrect the severe metabolic acidosis. In other patients large amounts of sodium bicarbonate were given but without the concomitant use of salt-removing diuretics such as furosemide. Consequently, in several patients serum sodium rose to unacceptably high levels, in one patient to $192 \mathrm{mEq} / \mathrm{L}$ after the administration of over 700 $\mathrm{mEq}$ of sodium bicarbonate. Such high levels could not fail to produce a fluid overload with consequent further strain on a cardiovascular system already embarrassed by grossly abnormal blood levels of potassium, calcium, hydrogen ions, carbon dioxide, and oxygen.

Although the acidosis of malignant hyperthermia is known to have an intracellular origin, ${ }^{68}$ THAM, which unlike sodium bicarbonate penetrates into the cell interior, was employed on only two occasions. ${ }^{1,32}$

\section{Respiratory acidosis (Table XXVII)}

Artificial hyperventilation was begun in many cases long after excessively high arterial carbon dioxide tensions had been recorded, and in many cases the minute volumes employed were far too small to correct these high arterial $\mathrm{CO}_{2}$ tension levels.

\section{Hypoxia (Table XXVII)}

The institution of 100 per cent inspired oxygen was often too late to prevent serious hypoxic damage.

\section{Abnormal serum potassium (Table XXVII)}

Early hyperkalaemia appeared to be a relatively transient phenomenon that was best managed by fairly conservative measures such as the administration of intravenous fluids and diuretics. The succeeding hypokalaemia required potassium 
replacement therapy. In not a few patients potassium salts were unfortunately given during the period of hyperkalaemia and withheld during the phase of potassium depletion.

\section{Membrane abnormalities (?) (Table XXVII)}

While all but two $0^{43,57}$ of the patients who received calcium died, one author ${ }^{29}$ did report that calcium gluconate injection was followed by a transient lessening of rigidity and improvement of the cardiovascular status, although the patient subsequently deteriorated and eventually died. Perhaps the temporary improvement observed was due to the stabilizing effect of calcium on the muscle cell membrane or to reduction in sensitivity of the post-synaptic receptor to acetylcholine.

The doses of steroids employed were too often in the physiological range - far too small to produce a sufficient effect in a medical emergency.

\section{Coagulation abnormalities (Table XXVII)}

The impaired blood coagulation was treated with a variety of agents, anticoagulants (heparin and coumadin) and coagulants (protamine, vitamin $\mathrm{k}$, epsilon amino caproic acid, cryoglobulin, fibrinogen, and fresh frozen plasma). Their use did not appear to affect the survival rate, and insufficient laboratory data were available to indicate whether or not they improved the coagulation defect.

\section{Renal failure (Table XXVII)}

Diuretics were given in several patients only after the renal tubules had become irreversibly obstructed with haemoglobin and/or myoglobin. Thus their use was not only ineffective but actually dangerous. Those patients ${ }^{9,43,57}$ who received diuretics such as furosemide and mannitol early (usually within one hour of the induction of anaesthesia), maintained good urine volumes throughout the course of the disease in spite of persistent myoglobinuria.

Peritoneal or haemodialysis was employed only twice, once with rather spectacular success. ${ }^{17,62}$

\section{Cardiovascular abnormalities (Table XXVII)}

A variety of vasopressor agents of the $\alpha$ stimulator type were used, almost always without success. Their use was almost always for terminal shock and was perhaps therefore futile. However, the rationale for using this type of agent at all in a disease such as malignant hyperthermia was very dubious. ${ }^{69}$

A great assortment of other cardiovascular agents were also employed, e.g. cardiac glycosides, anti-arrhythmic agents, and vasodilators. The data were insufficient to permit any conclusive analysis. Theoretically the use of cardiac glycosides, a group of drugs which enhance muscle contractility by accelerating the influx of calcium ions into the sarcoplasm, would appear to be contraindicated in this condition. ${ }^{70}$

\section{Discussion}

In numerous instances, cases of hyperthermia have been divided into two groups on the basis of presence or absence of skeletal muscle rigidity. This divi- 
sion has been used extensively throughout this paper to make statistical comparisons within the group of hyperthermic patients. The procedure becomes empirically justified in that it reveals some differences associated with rigidity. The absence of a significant difference does not imply that the particular item under study is unimportant in malignant hyperthermia. It merely means that in this respect there is no difference between these two kinds of hyperthermic patients. Since we performed a retrospective study, there were very few suitable control data which permitted one to compare patients with and without hyperthermia.

Cases characterized by rigidity differed in a number of features from those in which rigidity was not observed. Rigidity was not infrequently associated with pre-existing congenital muscle or musculoskeletal disease. During hyperthermia, the following signs occurred almost exclusively in the rigid group: tachypnoea, tachycardia, arrhythmias, cynanosis, metabolic and respiratory acidoses, hypocalcaemia, impaired blood coagulation, haemo- and myoglobinuria and oliguria. During the recovery phase following the rigidity, one noticed elevated levels of CPK, SGOT, SGPT and LDH, in addition to muscle pain, stiffness, and alterations of muscle structure which were visible in biopsy specimens. These features were only rarely observed in the group of patients without rigidity. It is possible that these two groups of patients represent different disease entities, but one cannot exclude the possibility that the above clinical abnormalities are a consequence of the rigidity.

The latter hypothesis is supported by the observation that in a few instances both rigid and non-rigid cases occurred in the same family, but this could possibly be due to different modes of anaesthesia. The observation requires further investigation.

The pathophysiology of the fever, muscle rigidity, and the various laboratory abnormalities such as the acidosis, hypoxia, potassium abnormalities, and elevated serum enzymes will be dealt with in the latter part of the next paper. ${ }^{68}$

The tachypnoea most likely was due to a combination of hyperthermia, hypercarbia, hydrogen ion excess, and hypoxaemia.

Tachycardia and other arrhythmias and heart failure probably resulted from rigor of the heart muscle and from the deleterious effects of hyperkalaemia, metabolic and respiratory acidoses, and hypoxia upon the myocardium. Excessive use of intravenous fluids and sodium bicarbonate may also have helped in some cases to precipitate an acute high-output cardiac failure.

Renal failure arose not only from the plugging of the renal tubules by haemoglobin and myoglobin casts but also from the interference of myoglobin, hypercarbia, acidosis, and hypoxia with the renal microcirculation. Myoglobin because of its relatively small molecular size (about 12,000 as compared to 68,000 for haemoglobin) penetrates right into the renal interstitium.

Late neurological changes such as fixed and dilated pupils, convulsions, and coma were likely a reflection of acute cerebral oedema secondary to severe hypoxia, hypercarbia, and hyperthermia.

When one simply counts the therapeutic measures, none appears to have improved the survival rate. However, these enumerations do not take into consideration either the bias which is introduced by the much more liberal use of various 
forms of treatment in the more severely affected patients, or the differences in drug dosage, time of administration, and combinations of therapeutic measures. Nevertheless, without any therapy, the mortality might have been higher than it was. The survival rate was 23 per cent when first reported by us in $1967,{ }^{4}$ and it is about 36 per cent today, using the same methods of reporting. Therefore, overall management appears to be improving even though the cause remains obscure and no therapeutic "breakthroughs" have occurred. The improvement is presumably due to the greater awareness by anaesthetists of the need for early diagnosis, for immediate cessation of anaesthesia upon diagnosis and for prompt and judicious treatment.

\section{SUMMARY}

Information was collected on 89 patients who responded to general anaesthetics with malignant hyperthermia. The syndrome occurred at the rate of about one in 14,000 anaesthetics among a hospital population of children. The patient mortality was 64 per cent. The finding that males were somewhat more commonly affected than were females does not contradict previous observations of dominant inheritance of the syndrome. About one-third of patients had relatives who were also affected with malignant hyperthermia, although a few patients had had previous uneventful general anaesthetics. The racial origin was varied. A pre-existing muscle or musculoskeletal disease was present more frequently than expected in patients who manifested rigidity.

Clinical manifestations followed the administration of a muscle relaxant or a potent inhalational agent, usually halothane. Fever was invariably present within the first one to two hours of the induction. Skeletal muscle rigidity occurred in more than two-thirds of cases. The use of anticholinergic drugs given preoperatively appeared to increase the incidence of rigidity. The use of non-depolarizing relaxants in vain attempts to overcome the rigidity has certainly not improved the chances of survival. The higher the absolute maximum temperature and the longer the duration of anaesthesia, the greater was the mortality rate.

It is possible that the cases with and without rigidity represent slightly different disorders. In cases characterized by rigidity there were often tachypnoea, tachycardia, arrhythmias, acute heart failure, late neurological deterioration, hypoxia, respiratory and metabolic acidoses, hyperkalaemia, hypocalcaemia, elevated serum enzymes, impaired blood coagulation, haemo- and myoglobinuria, oliguria, and muscle biopsy abnormalities.

Treatment included a wide variety of therapeutic measures. No particular agent could be credited with having improved the survival rate. So far, the most effective treatment was early detection and early cessation of anaesthesia.

\section{RÉsUMÉ}

On a recueilli des renseignements chez $\$ 9$ malades qui ont présenté de l'hypothermie maligne au cours d'une anesthésie générale. Le syndrome est apparu au taux d'un pour 14,000 anesthésies parmi la clientèle d'un hôpital pour enfants. Le taux de mortalité a été de 64 pour cent. La constatation que les sujets de sexe 
masculin sont le plus fréquemment affectés ne contredit pas les observations précédentes. Environ un tiers des malades avaient vu des membres de leur famille souffrir d'hyperthermie maligne, cependant que quelques uns avaient déjà subi une anesthésie générale sans incidents. L’origine raciale était variée. Il y avait une maladie musculaire ou musculosquelettique pré-existante plus souvent qu'on ne s'y attendait chez les malades qui ont manifesté de la rigidité.

Les manifestations cliniques se sont produites après l'administration d'un myorésolutif ou d'un agent inhalatoire puissant, généralement l'halothane. On a toujours observé de la fièvre au cours de la première ou de la deuxième heure à compter de l'induction. La rigidité des muscles squelettiques s'est produite dans plus des deux tiers des cas. L'usage de produits anticholinergiques en médication préopératoire a semblé augmenter la fréquence de la rigidité. L’usage de résolutifs non dépolarisants, pour tenter en vain de combattre la rigidité, n’a certainement pas augmenté les chances de survie. Plus la température a été élevée et plus l'anesthésie a été longue, plus le taux de mortalité a été élevé. Il est possible que les cas avec ou sans rigidité représentent des pathologies légèrement différentes. Chez les malades présentant de la rigidité, il y avait souvent de la tachypnée, de la tachycardie, des arythmies, une défaillance cardiaque aigue, une détérioration neurologique tardive, de l'hypoxie, de l'acidose respiratoire et métabolique, de l'hypercaliémie, de l'hypocalcémie, une élévation des enzymes aériques, des troubles de la coagulation du sang, de l'hémoglobinurie, de la myoglobinurie, de l'oligurie et des anomalies de la biopsie musculaire.

Le traitement comprend une grande variété de mesures thérapeutiques. Aucun agent en particulier ne peut recevoir le crédit d'avoir amélioré le taux de survie. Pour le moment, le traitement le plus efficace a été le diagnostic précoce et la cessation rapide de l'anesthésie.

\section{ACKNOWLEDGMENTS}

We wish to thank the following anaesthetists who have personally referred cases of malignant hyperthermia to us: Dr. J. Beldavs, Dr. K. Bezai, Dr. P. Brooks, Dr. F. Raymon, Dr. D. Craig, Dr. N. E. Foster, Dr. A. Gygi, Dr. R. M. Kilbourn, Dr. E. Kirkebeck, Dr. J. C. Kruse, Dr. K. Kurita, Dr. W. G. Locher, Dr. M. Minuck, Dr. A. D. Pitonyak, Dr. J. Rein, Dr. F. Rigley, Dr. G. Sanderson, Dr. J. Wade, and Dr. R. L. Watson.

We also are deeply indebted to Dr. L. Endrenyi of the Department of Pharmacology of the University of Toronto for his invaluable assistance with the statistical analyses of this paper.

This work was supported by grants from Ayerst Laboratories and from the Medical Research Council of Canada (grant no. MA-2441).

\section{REFERENCES}

1. Brauticam, K. H. \& Seybold, R. Fehler und Gefahren: Hyperthermie durch Allgemeinanaesthesie. Anaesthesist. 18: 338 (1969).

2. Brits, B. A. \& Gondon, R. A. Three Cases of Malignant Hyperthermia with Special Consideration of Management. Canad. Anaesth. Soc. J. 16: 99 (1969). 
3. BRitr, B. A.; Locher, W. G.; \& KaLow, W. Hereditary Aspects of Malignant Hyperthermia. Canad. Anaesth. Soc. J. 16: 89 (1969).

4. Brutr, B. A. \& Kalow, W. Hyperrigidity and Hyperthermia Associated with Anaesthesia. Ann. New York Acad. Sc. 151: 947 (1968).

5. Captzzi, L. S.; Phullips, O. C.; \& Harris, L. C. Malignant Hyperthermia during Anaesthesia. Anesthesiology. 31: 97 (1969).

6. Carpenter, G. G.; Auerbach, V. H.; Digeonge, A. M.; Mayer, B. W.; \& Schutta, H. S. Rhabdomyolysis after Routine Administration of Succinylcholine in Children. Soc. Paediat. Res. 29-30: 175 (1966).

7. Churchill-Davmson, W. Malignant Hyperpyrexia. Brit. Med. J. 3: 69 (1968).

8. CoDy, J. R. Muscle Rigidity Following Administration of Succinylcholine. Anesthesiology. 29: 159 (1968).

9. Crocker, D.; Blum, H.; Adams, J. G.; \& Smith, R. M. Hyperthermia during Anaesthesia. Anaesth. \& Analg. 48: 789 (1969).

10. Cullen, W. G. Malignant Hyperpyrexia during General Anaesthesia: A Report of Two Cases. Canad. Anaesth. Soc. J. 13: 437 (1966).

11. Daniels, J. C.; Polayes, I. M.; Villar, R.; \& Hehre, F. W. Malignant Hyperthermia with Disseminated Intravascular Coagulation during General Anaesthesia: A Case Report. Anaesth. \& Analg. 48: 877 (1969).

12. Davies, L. E. \& Graves, H. B. Hyperpyrexia and Death Associated with General Anaesthesia. Canad. Anaesth. Soc. J. 13: 447 (1966).

13. Davies, R. M.; Packer, K. J.; Titel, J.; \& Whitmarsh, V. Malignant Hyperpyrexia: Two Case Reports. Brit. J. Anaesth. 41: 703 (1969).

14. Denborough, M. A. \& Lovels, R. R. H. Anaesthetic Deaths in a Family. Lancet. ii: 45 (1960).

15. Denbonough, M. A.; Fonster, J. F. A.; Lovell, R. R. H.; Maplestone, P. A.; \& Villers, J. D. Anaesthetic Deaths in a Family. Brit. J. Anaesth, 34: 395 (1962).

16. Drlon, J. B. Fulminating Hyperthermia during Anaesthesia. New York State J. Med. 68 : 2566 (1968).

17. Gibson, J. A. \& Gardiner, D. M. Malignant Hypertonic Hyperpyrexia Syndrome. Canad. Anaesth. Soc. J. 16: 106 (1969).

18. Gondon, R. A. Malignant Hyperpyrexia during General Anaesthesia. Canad. Anaesth. Soc. J. 13: 415 (1966).

19. Guedel, A. E. Inhalation Anaesthesia. 2nd ed., New York: Macmillan (1952), p. 110.

20. Hogg, S. \& Renwick, W. Hyperpyrexia during Anaesthesia. Canad. Anaesth. Soc. J. 13: 429 (1966).

21. Katsya, H. Malignant Hyperpyrexia: A Case Report. Japan J. Anaesth. 44: 661 (1969).

22. KNIGir, R. T. Elevation of Body Temperature during Anaesthesia and Its Control. Anaesth. \& Analg. 21: 117 (1942).

23. Lavoie, G. Hyperpyrexia during General Anaesthesia: A Case Report. Canad. Anaesth. Soc. J. 13: 444 (1966).

24. Mantin, J. T. Fulminant Hyperthermia. J.A.M.A. 204: 183 (1968).

25. Marx, G. F.; Steen, S. N.; Berenyi, K. J.; Erlanger, H. L.; Foster, E. S.; Kepes, E. R.; Jadwat, C. M.; Potash, R. S.; \& Schapira, M. Fulminating Hyperthermia during Anaesthesia: A Case Report. New York State J. Med. 68: 2566 (1968).

26. Mogavock, H. A Simple Method for the Early Detection of the Malignant Hyperpyrexia of Anaesthesia and Hypothesis. Ir. J. Med. Sc. 2: 285 (1969).

27. Murray, B. R. P. \& Williams, P. A. D. Malignant Hyperpyrexia during Anaesthesia for Collectomy. Brit. Med. J. 1: 488 (1969).

28. P.S.M., Mass. Comment on Case Report \#247. Am. Soc. Anesth. Newsletter. 26: 10 (1962).

29. Punkis, I. E.; Horrett, O.; De Young, G.; Fleming, R. A. P.; \& Langlex, G. R. Hyperpyrexia Following Anaesthesia in a Second Member of a Family with Associated Coagulation Defect. Canad. Anaesth. Soc. J. 14: 183 (1967).

30. Quinn, J. R.; Spatz, S. S.; Shensa, D. R.; \& Esway, J. K. Malignant Hyperthermia during an Oral Surgical Procedure: Report of a Case. J. Oral Surg. 27: 266 (1969).

31. Relton, J. E. S.; Creighton, R. E.; Johnston, A. E.; Pelton, D. A.; \& Conn, A. W. Hyperpyrexia in Association with General Anaesthesia in Children. Canad. Anaesth. Soc. J. 13: 419 (1966).

32. Relton, J. E. S.; Creighton, R. E.; Conn, A. W.; \& Nabeta, S. Generalized Muscular 
Hypertonicity Associated with General Anaesthesia: A Suggested Anaesthetic Management. Canad. Anaesth. Soc. J. 14: 22 (1967).

33. Relton, J. E. S.; Creighton, R. E.; \& Conn, A. W. Fulminant Hyperpyrexia Associated with Anaesthesia. Anaesthesia. 23: 253 (1968).

34. Ruttle, L. D. Case Report \#247: Death Occurred in the Operating Room Following Extreme Hyperthermia during an Elective Cholecystectomy. Am. Soc. Anesth. Newsletter. 26: 21 (1962).

35. Samdman, L. J.; Havard, E. S.; \& Eger, E. I. Hyperthermia during Anesthesia. J.A.M.A. 190: 73 (1964).

36. SAtnick, J. H. Hyperthermia under Anesthesia with Regional Muscle Flaccidity. Anesthesiology. 30: 472 (1969).

37. Soderberg, M. J. Anesthesia and Malignant Hyperpyrexia. J. Am. A. Nurse Anesthetists. Oct., 368 (1969).

38. Stephen, C. R. Fulminant Hyperthermia during Anaesthesia and Surgery. J.A.M.A. 202: $178(1967)$.

39. Takamatsu, $O$. Three Cases of Malignant Hyperpyrexia during Anaesthesia. Japan J. Anaesth. 44: 665 (1969).

40. Thuт, W. H. \& Davenport, H. T. Hyperpyrexia Associated with Succinylcholine-Induced Muscle Rigidity: A Case Report. Canad. Anaesth. Soc. J. 13: 425 (1966).

41. W.A.C., Calif. Comments on Case Report \#247. Am. Soc. Anesth. Newsletter. 26: 30 (1962).

42. Wilson, R. D.; Dent, T. E.; Traber, D. L.; McCoy, N. R.; \& Allen, C. R. Malignant Hyperpyrexia with Anesthesia. J.A.M.A. 202: 183 (1967).

43. Beldavs, J. Personal Communication. Windsor, Ontario (1969).

44. Brzar, K. Personal Communication. Detroit, Michigan (1969).

45. Brooks, P. Personal Communication. Orlando, Florida (1969).

46. Chaig, D. Personal Communication. Montreal, Que. (1969).

47. Drx, G. W. Personal Communication. Toronto, Ontario (1969).

48. Foster, N. E. Personal Communication. Calgary, Alberta (1968).

49. Grar, A. Personal Communication. Geneva, Switzerland (1969).

50. Kilbourn, R. M. Personal Communication. Kitchener, Ontario (1967).

51. Krrkebeck, E. Personal Communication. Calgary, Alberta (1969).

52. Kruse, J. C. Personal Communication. Jacksonville, Florida (1968).

53. Kunita, K. Personal Communication. Modesto, California (1969).

54. Lochen, W. G. Personal Communication. Wausau, Wisconsin (1968).

55. Minuck, M. Personal Communication. Winnipeg, Manitoba (1969).

56. Pitonyak, A. D. Personal Communication. Pontiac, Michigan (1969).

57. Raymon, F. \& Bruce, D. Personal Communication. Chicago, Ill. (1969).

58. Reis, J. Personal Communication. Suffern, N.Y. (1969).

59. Riclex, F. Personal Communication. Montreal, Quebec (1968).

60. Sanderson, G. Personal Communication. Buffalo, N.Y. (1968).

61. Stephen, C. R. Personal Communication. Dallas, Texas (1967).

62. Wade, J. Personal Communication. Winnipeg, Manitoba (1969).

63. Watson, R. L. Personal Communication. Washington, D.C. (1969).

64. WeBb, G. E. Personal Communication. Madison, Wisconsin (1968).

65. Orkin, L. Personal Communication. New York, N.Y. (1969).

66. Ryan, J. F. \& Papper, E. M. Malignant Fever during and Following Anesthesia. Anesthesiology, 32: 196 (1970).

67. Seeman, P. Personal Communication. Toronto, Ontario (1968).

68. Brutt, B. A. \& Kalow, W. Malignant Hyperthermia: Aetiology Unknown. Canad. Anaesth. Soc. J. 17: 316 (1970).

69. Lilleher, R. C.; Longerbeam, J. K.; Bloch, J. H.; \& Manax, W. G. The Modern Treatment of Shock Based on Physiologic Principles. Clin. Pharmacol. Therap. 5: 63 (1964).

70. Косн-Weser, J. Mechanism of Digitalis Action on the Heart. New England J. Med. 277: 469 (1967). 